\title{
"Strategic and tactical benchmarks for restructuring the financial system of
}

Ukraine"

\begin{tabular}{|c|c|}
\hline \multirow{5}{*}{ AUTHORS } & Serhiy Frolov (D) \\
\hline & $\mathbf{R}$ \\
\hline & Volodymyr Orlov (iD) \\
\hline & Olha Lozynska (i) \\
\hline & Fathi Shukairi (iD) \\
\hline ARTICLE INFO & $\begin{array}{l}\text { Serhiy Frolov, Volodymyr Orlov, Olha Lozynska and Fathi Shukairi (2021). } \\
\text { Strategic and tactical benchmarks for restructuring the financial system of } \\
\text { Ukraine. Economics of Development, 20(1),11-22. } \\
\text { doi:10.21511/ed.20(1).2021.02 }\end{array}$ \\
\hline DOI & http://dx.doi.org/10.21511/ed.20(1).2021.02 \\
\hline RELEASED ON & Friday, 25 June 2021 \\
\hline RECEIVED ON & Friday, 22 January 2021 \\
\hline \multirow[t]{2}{*}{ ACCEPTED ON } & Wednesday, 17 March 2021 \\
\hline & $((c))$ EY \\
\hline LICENSE & $\begin{array}{l}\text { This work is licensed under a Creative Commons Attribution } 4.0 \text { International } \\
\text { License }\end{array}$ \\
\hline JOURNAL & "Economics of Development" \\
\hline ISSN PRINT & $1683-1942$ \\
\hline ISSN ONLINE & $2304-6155$ \\
\hline PUBLISHER & LLC "Consulting Publishing Company "Business Perspectives" \\
\hline FOUNDER & Simon Kuznets Kharkiv National University of Economics \\
\hline
\end{tabular}

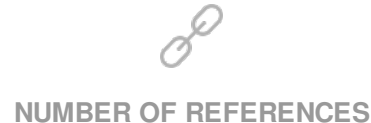

18

\section{NUMBER OF FIGURES}

3
NUMBER OF TABLES

1

(C) The author(s) 2021. This publication is an open access article. 


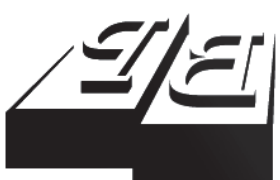

BUSINESS PERSPECTIVES

Publisher

LLC "CPC "Business Perspectives" Hryhorii Skovoroda lane, 10, Sumy, 40022, Ukraine www.businessperspectives.org

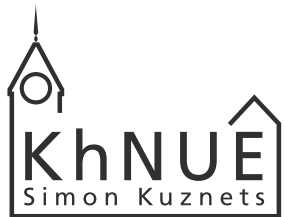

\section{S. KUZNETS KHNUE}

\section{Founder}

Simon Kuznets Kharkiv National University of Economics, Nauky avenue, 9-A, Kharkiv, 61166,

Ukraine

http://www.hneu.edu.ua/

Received on: 22nd of January, 2021 Accepted on: 17th of March, 2021 Published on on: 25th of June, 2021

() Serhiy Frolov, Volodymyr Orlov, Olha Lozynska, Fathi Shukairi, 2021

Serhiy Frolov, Doctor of Economics, Professor, Head of Department of State, Local and Corporate Finance, University of Customs and Finance, Ukraine.

Volodymyr Orlov, Ph.D. in Economics, Associate Professor, University of Customs and Finance, Ukraine.

Olha Lozynska, Ph.D. Student, Simon Kuznets Kharkiv National University of Economics, Ukraine.

Fathi Shukairi, Ph.D. Student, University of Customs and Finance, Ukraine.

\section{(c) (i)}

This is an Open Access article, distributed under the terms of the Creative Commons Attribution 4.0 International license, which permits unrestricted re-use, distribution, and reproduction in any medium, provided the original work is properly cited.
Serhiy Frolov (Ukraine), Volodymyr Orlov (Ukraine), Olha Lozynska (Ukraine), Fathi Shukairi (Ukraine)

\section{STRATEGIC AND TACTICAL BENCHMARKS FOR RESTRUCTURING THE FINANCIAL SYSTEM OF UKRAINE}

\begin{abstract}
General trends of the current stage of development of the world and domestic economies confirm the most important trends of financial systems of the leading countries, including Ukraine. Among them, it is advisable to highlight the following: financial inclusion, formation of an unassailable reputation by financial institutions, reducing the volume of shadow banking, increasing the level of the population's financial literacy, developing financial technologies, and deepening the financial system. All of this involves increasing the size of financial assets in relation to the size of the economy based on the GDP indicator. Based on the results of generalizing the approaches of scientists to the list of determining factors affecting the development of the country's financial system, the key role of the level of financial literacy of the population was established. The article presents the total index of financial literacy of the population of individual countries of Europe and the world based on the index components.

The development of the financial system in all these areas creates conditions for a gradual transition to the development of a new quality financial ecosystem. The article proposes a definition of the financial ecosystem in the context of established hybrid of real and digital space based on the integration of financial institutions as key players with technology companies, public service providers and other participants. To ensure development, the advantages and disadvantages are specified based on the results of the SWOT analysis, which allowed to systematize the strengths and weaknesses, as well as the opportunities and threats of the financial ecosystem development. Based on the results of the analysis, four basic strategies for restructuring the financial system were developed, which are the basis for proposals for the development of the financial ecosystem and changing the business models of functioning of its subjects in Ukraine.
\end{abstract}

Keywords

JEL Classification financial system restructuring, financial inclusion, financial ecosystem, SWOT analysis

G30, G38, G39
С. М. Фролов (Україна), В. В. Орлов (Україна),

О. І. Лозинська (Україна), Ф. Шукаірі (Україна)

\section{СТРАТЕГІЧНІ I ТАКТИЧНІ ОРІЕНТИРИ РЕСТРУКТУРИЗАЦІЇ ФІНАНСОВОЇ СИСТЕМИ УКРАЇНИ}

\section{Анотація}

Загальні тенденції сучасного етапу розвитку глобальної та вітчизняної економіки підтверджують найважливіші напрямами розвитку фінансових систем країн провідних країн світу, в тому числі й України, серед яких доцільно виділити наступні: фінансова інклюзія, формування фінансовими установами бездоганної репутації, зменшення обсягів тіньового банкінгу, підвищення рівня фінансової грамотності населення, розвиток фінансових технологій, а також нарощення глибини фінансової системи, що передбачає збільшення розміру фінансових активів відносного розміру економіки на основі показника обсягу валового внутрішнього продукту. За результатами узагальнення підходів науковців до переліку визначальних факторів впливу на розвиток фінансової системи країни встановлено ключову роль рівня фінансової грамотності населення. У статті на основі складових індексу представлено сумарний індекс фінансової грамотності населення окремих країн Європи та Світу.

Розвиток фінансової системи за усіма зазначеними напрямами створює умови для поступового переходу до формування фінансової екосистеми нової якості. В роботі запропоновано визначення фінансової екосистеми в контексті створеного гібридного реально-цифрового простору на основі інтеграції фінансових установ як головних учасників 3 технологічними компаніями, установами, що надають публічні послуги та інших учасників. 3 метою 
забезпечення розвитку конкретизовано переваги та визначено недоліки на основі результатів використання SWOT-аналізу, що дозволило систематизувати сильні та слабкі сторони, а також можливості та загрози формування фінансової екосистеми. Виходячи з результатів аналізу, було сформовано чотири базові стратегії реструктуризації фінансової системи, які покладено в основу пропозицій щодо формування фінансової екосистеми та зміни бізнес-моделей функціонування їі суб'єктів в Україні.

$\begin{array}{ll}\text { Ключові слова } & \text { реструктуризація фінансової системи, фінансова інклюзія, фінансова екосистема, SWOT-аналіз } \\ \text { Класифікація JEL } & \mathrm{G} 30, \mathrm{G} 38, \mathrm{G} 39\end{array}$

\section{ПОСТАНОВКА ПРОБЛЕМИ}

Фінансові кризи глобального масштабу виступають певним тригером змін у світовій фінансовій архітектурі. Зокрема світова фінансова криза 2008 року призвела до кардинальних змін в каркасі регулювання фінансової системи США та Європейського Союзу. Вивчення провідного світового досвіду, узагальнення підходів до вирішення проблемних практичних аспектів розвиткуекономікдозволить через реструктуризацію вітчизняної фінансової системи забезпечити в першу чергу фінансову стабільність і в подальшому зростання ВВП.

\section{1. ЛІТЕРАТУРНИЙ ОГЛЯА}

Питанням аналізу, функціонування та розвитку фінансової системи країн присвячено ряд публікацій як вітчизняних науковців, серед яких Благун [1], Довгань [4], так і зарубіжних науковців: Metrick, Rhee [12], Cerra, Saxena [2], Georgieva [6], Čihák, Sahay [3], Li, Liu, Wang [10]. Разом з тим певні проблемні питання реструктуризації в умовах фінансових криз, розвитку цифрової економіки, залишаються недостатньо дослідженими. Це обумовило вибір теми та мету дослідження.

\section{2. МЕТА ДОСЛІДЖЕННЯ}

Метою статті є дослідження теоретичних положень і практичних аспектів функціонування та розвитку фінансових систем країн світу, їх узагальнення та розробка рекомендацій щодо вибору стратегій реструктуризації фінансової системи України.

\section{3. РЕЗУЛЬТАТИ}

Основною метою змін функціонування фінансових систем було визначено регулювання та контроль за системним ризиком. При цьому аналіз всього спектру регулювання системного ризику з точки зору діючих та запроваджених нормативних регулятивних актів умовно поділено на три групи: превентивні повноваження, надзвичайні повноваження та повноваження щодо вирішення та реструктуризації. Представники школи менеджменту Єльського університету Метрік та Pi [12], систематизувавши основні заходи, що були здійснені в сфері фінансового регулювання визначили ключові елементи регулювання системним ризиком, з якими цілком погоджуємось. Найбільш вагомим в системі фінансового регулювання $\epsilon$, по-перше, реформування Базельської системи банківського нагляду. Зокрема зміни в банківському регулюванні та нагляді, що знайшли своє відображення в Базель III, в першу чергу, були спрямовані на визначення адекватного розміру та якості капіталу, зростання рівня ліквідності в банківській системі. По-друге, важливим залишається формування зв’язків між учасниками фінансовими ринками та фінансовими системами різних регіонів та різних країн, що призвело до формування умов для переливу капіталу між різними сегментами фінансового ринку та між ринками різних країн. По-третє, значна увага приділяється процедурам забезпечення прозороїі діяльності банків. По-четверте, здійснюється і продовжує здійснюватись розробка нових підходів в стрес-тестуванні, в аспекті моніторингу фінансової стабільності, а також висунуті посилені вимоги до центрального клірингу похідних фінансових інструментів. 
Варто зазначити, що за даними Церра та Саксен в середньому фінансова криза призводить до втрат обсягів виробництва в розмірі 10\% [2]. В своєму виступі напочатку 2020 року директор-розпорядник МВФ Георгієва зазначала, що найбільш серйозними, є виклики, які обумовлені змінами клімату [6]. Водночас, ситуація 2020 року, яка склалась в наслідок пандемії коронавіруса COVID-19 показала, що цей виклик $\epsilon$ дуже вагомим із значним впливом на стан фінансових систем. Це обумовило необхідність перегляду урядами багатьох країн фінансових програм та перенаправлення фінансових ресурсів на проведення досліджень в боротьбі з пандемією. В Україні ця проблема в основному вирішується за рахунок коштів державного та частково місцевих бюджетів. При цьому впровадження карантинних заходів, введення локдауну призводить до спаду економічної активності та, як наслідок, уповільнення темпів економічного зростання. Це матиме також наслідки на стан розвитку фінансової системи в цілому. Водночас варто очікувати ще й прогнозованого відкладеного негативного ефекту, що проявиться у зростанні обсягів непогашених кредитів. Особливо це, в першу чергу, стосуватиметься кредитів, наданих малому та середньому бізнесу.

В Стратегії розвитку фінансового сектору України до 2025 року [15], яка підписана всіма регуляторами фінансової системи України - Національним банком України, Міністерством фінансів України, НКЦПФР та Фондом гарантування вкладів фізичних осіб одним із напрямів визначено розвиток фінансової інклюзії, яка передбачає підвищення доступності та рівня користування фінансовими послугами; посилення захисту прав споживачів фінансових послуг а також підвищення рівня фінансової грамотності населення. Фінансова інклюзія за визначенням Організації економічного співробітництва та розвитку (ОЄСР) розглядається як «процес просування доступного, вчасного та повноцінного доступу до широкого спектру фінансових продуктів і послуг, поширення їхнього використання серед всіх прошарків суспільства через впровадження існуючих та інноваційних підходів включно з фінансовою обізнаністю та освітою з метою просування як фінансового добробуту, так і економічної та соціальної інклюзї̈ [14].

В контексті дослідження фінансової інклюзії варто зазначити, що рівень включення населення України до користування фінансовими послуг за даними Світового банку є достатньо низький. Так станом на початок 2018 року 63\% населення, старше 15 років мають відкритий рахунок у фінансових установах, при цьому динаміка цього показника є позитивною, оскільки станом за 2011 рік частка населення становила лише 41\%. Даний показник є дещо меншим ніж в середньому за світовий показник, який становить $69 \%$ станом за 2018 рік. Водночас в умовах пандемії суттєво зросли розрахунки онлайн, що могло спричинити і зростання зазначеного показника, але наразі офіційної статистики за даним показником немає. В кінці 2020 року Національний банк України розпочав роботу над Національною стратегією фінансової інклюзії. За даними Світового банку переважна більшість країн світу (понад 100) впроваджують національні стратегії фінансової інклюзії.

Національним банком України протягом останніх років здійснено низку заходів щодо забезпечення прозорості діяльності банків і наразі банківський сектор серед всіх сегментів фінансової системи $\epsilon$ максимально прозорим, чого не можна відзначити про небанківські фінансові установи. Тому подальшу діяльність фінансових регуляторів, i, в першу чергу Національного банку, буде зосереджено саме в цьому напрямі.

Дослідження параметрів тіньового банкінгу дозволили зазначити, що в даному випадку розуміється діяльністьфінансовихкомпаній,якіздійснюютькредитуванняфізичнихосібвсегментімікрокредитування, споживчих кредитів. Даний сегмент відрізняється низьким рівнем прозорості. Зростання його обсягів обумовлено цілим рядом чинників: по-перше, низьким рівнем кредитоспроможності населення, що змушує звертатись не до банківських установ, що здійснюють перевірку документів та оцінюють ризики, а до фінансових установ, які надають кредити під більш високі відсотки, але не вимагають підтвердження кредитоспроможності; по-друге, діяльність фінансових установ в частині надання кредитів, повністю не врегульована, а тому надає можливість вести недобросовісну підприємницьку діяльність, надавати неправдиву інформацію щодо фінансових послуг, зокрема в частині «безвідсоткових» кредитів; потретє низький рівень фінансової грамотності населення, в результаті чого споживачі послуг не можуть визначити свої реальні ризики, визначити загальну вартість отриманих кредитів, яка $є$ надто висока. 
Передача нагляду за діяльністю фінансових установ до повноважень Національного банку України передбачає створення максимально прозорих умов їх діяльності, врегулювання джерел фінансових ресурсів, запровадження ризик-орієнтованого підходу у нагляді за діяльністю, але при цьому, на відміну від банків, регуляторне середовище повинно бути спрощеним.

Доведено, що суттєву роль в реструктуризації фінансової системи відіграє рівень фінансової грамотності населення. Україна станом на початок 2019 року за індексом фінансової грамотності має найнижчі показники, порівняно з країнами ОЕСР (Рисунок 1).

Так при максимальному значенні індексу в 14.9, яке належить Франції, Україна має значення в 11.6, аналогічний показник має Польща та дещо вищий - 11.7 має Білорусь.

Даний показник включає три складові: ставлення до фінансових питань, що передбачає наявність короткострокового чи довгострокового мислення, бажання витрачати чи заощаджувати; фінансова поведінка - вміння планувати, заощаджувати, здатність порівнювати фінансові продукти; знання своїх прав як споживача фінансових послуг, вміння користуватись фінансовими послугами, в тому числі банківськими рахунками, укладанням страхових договорів, розуміння гарантованої суми відшкодування за вкладами в банках.

В сумарному індексі фінансової грамотності населення України ставлення до фінансових питань має найнижче значення на рівні 2.4; рівень знань також один із найнижчих - 4, менше значення має лише Білорусь. Водночас показник, що характеризує фінансову поведінку населення є досить високим - 5.2, аналогічний рівень мають Нідерланди та Албанія. Польща, яка має значно вищий рівень розвитку економіки в цілому та фінансової системи зокрема, має значення таке ж як і Україна, але інше співвідношення: вище значення показника ставлення до фінансових питань та знання, але значно нижче від України значення фінансової поведінки населення. Прийняття Національної стратегії фінансової інклюзії дозволить також суттєво підвищити рівень фінансової грамотності населення, що також буде мати позитивний вплив і на стан фінансової системи.

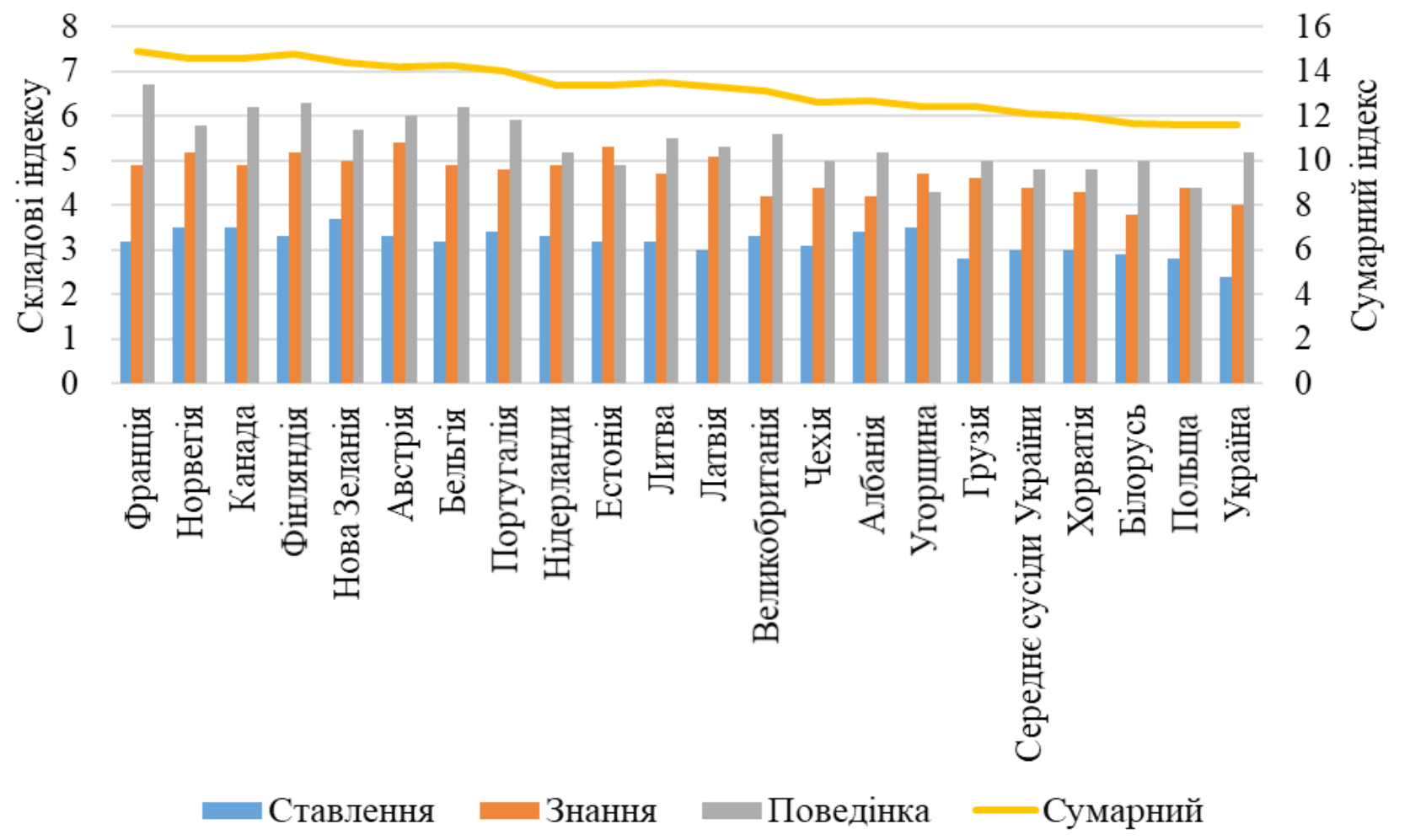

Рисунок 1. Індекс фінансової грамотності населення (станом на початок 2019 року) 
Посилення фінансової грамотності та фінансової інклюзії буде сприяти нарощенню глибини фінансової системи. Певний рівень глибини фінансової системи супроводжується зростанням нерівності та менш інклюзивним зростанням [3].

Сучасний стан фінансової системи, система фінансових відносин, знаходиться під впливом розвитку фінансових технологій (ФінТех). Вплив ФінТех має прояв в появі нових інститутів таких як необанки, іншуртех. Але найбільші зміни відбуваються саме в технічній фінансовій інфраструктурі - це розвиток краудфандингових платформ, поява технологій блокчейн, розвиток маркет-плейсів, мобільних гаманців, тощо. Про значимість розвитку фінансових технологій свідчить прийнятий Міжнародним валютним фондом і Групою Світового банку Балійський пакет в області фінансових технологій. В ньому визначено 12 стратегічних напрямів, які рекомендовані на основі існуючого досвіду країн, які є членами Міжнародного валютного фонду та Світового банку.

Розвиток країн за визначеними напрямами може суттєво змінити як світову так і національну фінансову архітектуру. По-перше це передбачає використання потенціалу фінансових технологій для розвитку фінансових послуг, а також створення відповідних умов. Це передбачає здійснення інвестицій в підтримуючу інфраструктуру, що дозволить в тому числі вирішити питання фінансової інклюзії. Розвиток фінансових технологій може сприяти формуванню конкурентного середовища, запровадженню єдиних «правил гри», розширенню доступу до якісних фінансових послуг (Рисунок 2).

Класичні фінансові установи впроваджують фінтех-підходи та укладають угоди з фінтех компаніями. Формуванню фінансової екосистеми передує перехід від надання фінансових послуг у традиційний спосіб до надання їх з використанням онлайн технологій. При цьому поступово онлайн послуги із інноваційних перетворюються в традиційні послуги.

Варто також зазначити, що в Україні ведеться активна робота щодо можливості запровадження цифрової валюти - е-гривні. Це також було підтверджено представниками Національного банку України під час опитування Світовим банком. Близько 20\% від опитуваних центральних банків (всього було опитано 96 представників банків) підтвердили, що вони досліджують дане питання. Так в пілотному режимі випуск цифрової валюти здійснено в Уругваї, при цьому Китай, Швеція, Багамські острови та СхідноКарибський валютний союз та Україна підтвердили, що планують здійснити такий випуск.

Зокрема в Стратегії розвитку фінансового сектору України до 2025 року [15], зазначається про створення фінансової екосистеми. Зазначено, що «потреби всіх субєєктів економічної діяльності мають бути задоволені через надання відповідних фінансових послуг учасниками фінансової екосистеми» [15]. Визначено також 4 групи суб'єктів - провайдери фінансових послуг, інфраструктура та технології, регуляція та контроль, експертиза - які в сукупності створюють всю екосистему. Водночас варто відзначити, що в даному документі, як і в будь-якому іншому офіційному документі в Україні не надано визначення, що таке фінансова екосистема, та в чому пї ключова відмінність від традиційного розуміння фінансової системи.

Пяняття екосистема почали активно використовувати в інформаційних технологіях і поступово, з врахуванням вагомої ролі останніх в розвитку фінансової системи став застосовуватись і при формуванні учасниками фінансових відносин. Наразі в наукових публікаціях українських авторів та авторів з інших країн проводяться дослідження щодо змісту фінансової екосистеми та особливостей iï формування. Зокрема в роботі Благуна [1] зазначається, що «зародження екосистеми наразі відбувається навколо банків і передбачає зміну концепції надання послуг, а також перехід до клієнтоцентризму тобто коли послуга здійснюється електронним каналом обслуговування під індивідуальний запит клієнта». І відповідно під фінансовою екосистемою автором запропоновано розуміти «як сукупність провайдерів послуг (фінансових і нефінансових установ), інститутів інфраструктури (професійних учасників фінансового ринку, технологічних компаній, стартапів), органів регуляції та контролю, а також експертного середовища, які діють на засадах колаборації з дотриманням принципів сталого розвитку задля надання інтегрованих послуг з орієнтацією на індивідуальний профіль споживачів - економічних 
Традиційні фінансові послуги (передбачають фізичну присутність клієнта у відділенні) трансформуються у діджиталізовані послуги

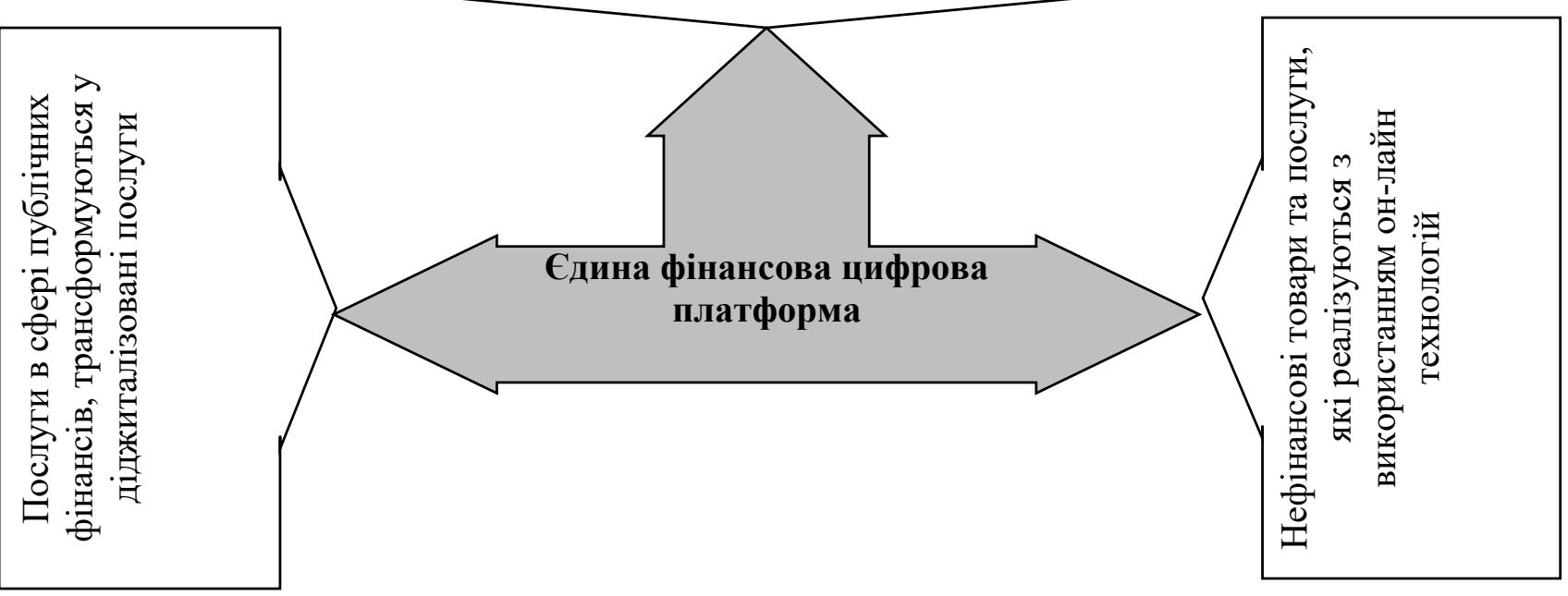

Джерело: Складено авторами

Рисунок 2. Надання послуг через єдину цифрову платформу як передумова формування фінансової екосистеми

агентів» [1]. Таке визначення по суті опирається на ту суб'єктну структуру, яка визначена в Стратегії розвитку фінансового сектору України до 2025 року з уточненням відносин між ними.

На думку Довгань «Фінансова екосистема це логічне продовження вирішення всіх питань у режимі онлайн, у тому числі за допомогою мобільних додатків, чат-ботів, онлайн-помічників і т. д.» [4]. В роботі Лi, Ліу, Ванг [10] зазначено, що «фінансова екосистема відноситься до динамічної системи рівноваги, в якій фінансова галузь та її зовнішнє середовище для виживання та розвитку взаємодіють між собою за допомогою власних механізмів коригування».

3 врахуванням результатів проведеного аналізу в аспекті вивчення особливостей формування фінансової екосистеми на прикладі потужних міжнародних корпорацій нами запропоновано під фінансовою екосистемою розуміти створений гібридний реально-цифровий простір внаслідок інтеграції фінансових установ як головних учасників з технологічними компаніями, установами, що надають публічні послуги (в т.ч. в сфері публічних фінансів) та інших учасників, об’єднаних єдиною ідеологією надання клієнту (фізичній чи юридичній особі) широкого спектру послуг фінансового та нефінансового характеру за принципом єдиної точки доступу на базі єдиної цифрової платформи. При цьому акцент в отриманні прибутку зміщується з отримання прибутку за рахунок конкретної операції до отримання прибутку за рахунок сформованого синергетичного ефекту від комплексного обслуговування клієнта в умовах функціонування цифрової економіки.

Формування фінансової екосистеми з одного боку має значні переваги, а з іншого - може формувати суттєві ризики як для клієнтів, так й для фінансових установ. Для визначення переваг та недоліків доцільно використати SWOT-аналіз, за результатами якого систематизуються сильні та слабкі сторони, а також можливості та загрози. Запровадження інструменту SWOT-аналізу дозволяє здійснювати саме коригування стратегічних орієнтирів та визначати оперативні завдання розвитку (Таблиця 1).

Отже сильними сторонами для клієнтів є насамперед доступ до послуг за допомогою єдиного вікна, тобто клієнт може отримати максимальну кількість послуг як фінансового так і нефінансового характеру, використовуючи єдину точку доступу. Високий рівень фінансової свободи для клієнта означає можливість 
швидко змінити фінансову установу, у випадку, якщо остання не відповідає очікуванням щодо якості обслуговування, при цьому під якістю обслуговування мається на увазі кількість запропонованих послуг та швидкість отримання послуги, що вимірюється кількістю кліків (процедур), які потрібно зробити для отримання такої послуги.

Таблиця 1. Результати SWOT-аналізу формування фінансової екосистеми

Джерело: Складено авторами

\begin{tabular}{|c|c|}
\hline Сильні сторони (Strengths) & Слабкі сторони (Weaknesses) \\
\hline $\begin{array}{c}\text { Для клієнтів: } \\
\text { - доступ через єдине вікно; } \\
\text { - високий рівень фінансової свободи; } \\
\text { - висока швидкість обслуговування; } \\
\text { - прозорість установи для клієнта; } \\
\text { - клієнтоцентризм; } \\
\text { - можливість здійснення операцій будь-де і будь-коли за } \\
\text { принципом доступ 24/7. }\end{array}$ & $\begin{array}{c}\text { Для клієнтів: } \\
\text { - низький рівень фінансової грамотності (низька здатність до } \\
\text { самостійного планування фінансових потоків); } \\
\text { - зниження рівня закритості персональної фінансової } \\
\text { інформації; } \\
\text { - відсутність якісного доступу до інтернету. }\end{array}$ \\
\hline $\begin{array}{c}\text { Для установи: } \\
\text { - єдина цифрова платформа; } \\
\text { - створення більш точного комплексного профілю клієнта; } \\
\text { - зміна фрінансової культури; } \\
\text { - прозорість клієнта для компанії; } \\
\text { - інноваційність діяльності; } \\
\text { - партнерство та апетит до ризику; } \\
\text { - побудова ефективних партнерських відносин з } \\
\text { технологічними компаніями та старт-апами. } \\
\end{array}$ & $\begin{array}{c}\text { Для установи: } \\
\text { - низький рівень фінансової інклюзії населення; } \\
\text { - суттєва нерівномірність доступу до фінансових послуг між } \\
\text { міським та сільським населенням; } \\
\text { - слабка можливість утримати зв'язок з клієнтом за відсутності } \\
\text { фізичного контакту; } \\
\text { - непристосованість законодавства та нездатність швидко } \\
\text { реагувати на потреби ринку. }\end{array}$ \\
\hline Можливості (Opportunities) & Загрози (Threats) \\
\hline $\begin{array}{c}\text { Для клієнтів: } \\
\text { - персоналізовані пропозиції та винагороди для клієнтів. }\end{array}$ & $\begin{array}{c}\text { Для клієнтів: } \\
\text { - знеособленість клієнта; } \\
\text { - низький рівень довіри до фінансових установ; } \\
\text { - високий рівень кіберзлочинності. }\end{array}$ \\
\hline $\begin{array}{c}\text { Для установи: } \\
\text { - створення нових бізнес-моделей для фінансових установ; } \\
\text { - єдність стратегій фінансових та нефінансових установ, } \\
\text { об'єднаних в еко-систему; } \\
\text { - залучення широкого кола клієнтів. }\end{array}$ & $\begin{array}{c}\text { Для установи: } \\
\text { - монополізація фрінансового ринку; } \\
\text { - високий рівень кіберзлочинності; } \\
\text { - відсутність єдиних технологічних стандартів надання послуг. }\end{array}$ \\
\hline
\end{tabular}

Прозорість установи для клієнта $є$ важливою перевагою при формуванні фінансової екосистеми. Варто зазначити, що НБУ розроблено та оприлюднено Проєкт Постанови Правління «Про затвердження Положення про вимоги до структури власності надавачів фінансових послуг» [18], який сприятиме формуванню прозорої структури власності установами, які надають фінансові послуги. Згідно документу, фінансові установи зобов’язані розкривати інформацію про всіх ключових учасників, а також власників істотної участі. При цьому в разі набуття істотної участі у власності установи, такий крок має бути погоджений з регулятором - НБУ, а також в структурі власності не мають бути присутніми особи, яким відповідно до чинного законодавства заборонено бути власником корпоративних прав або ж у інший спосіб мати суттєвий вплив на діяльність фінансової установи. В даному документі також враховано, що вимоги до небанківських фінансових установ щодо транспарентності їх структури власності $\epsilon$ спрощеними, порівняно з банками.

Прозора структура власностіє основою для відновлення довіри клієнтів до діяльності фінансової установи. Крім того НБУ планує до впровадження вимоги щодо дотримання фінансовими установами належної ринкової поведінки. Під останньою розуміється «спосіб ведення діяльності фінансовою установою, 
який передбачає іï відкритість і прозорість, бездоганну ділову репутацію власників та менеджменту, доброчесність і справедливе ставлення фінансової установи до клієнтів, увага до їх потреб, добросовісну конкуренцію відносно інших фінансових установ, недопущення шахрайства чи іншої протиправної діяльності, а також належну внутрішню організацію фінансової установи, яка забезпечує контроль за дотриманням вищезгаданих правил» [13].

Особливістю функціонування фінансової екосистеми є клієнтоцентризм, тобто концентрація на інтересах клієнта. Зміна концепції функціонування банків як головних фінансових посередників на клієнтоцентризм передбачає і зміну стратегічних фінансових таргетів - зміщення акцентів 3 максимізації прибутку від здійснення конкретних операцій доотримання синергетичного ефекту від надання комплексних послуг. Важливою перевагою такого підходу для клієнтів $€$ можливість здійснення операцій будь-де і будь-коли за принципом доступ 24/7.

Створення фінансової екосистеми дає цілий ряд переваг для фінансових установ. В першу чергу це створення єдиної цифрової платформи на якій можна пропонувати не тільки фінансові, а і нефінансові послуги, а також пропонувати придбання різноманітних товарів своїх партнерів. Для ефективного функціонування фінансових установ є створення більш точного комплексного профілю клієнта 3 використанням сучасних технологій, що дозволить досягати синергетичного ефекту, про який зазначено вище. Це також можливо за умови, якщо інформація про клієнта $є$ максимально прозорою. Компанії, які впроваджують концепцію клієнтоцентризму змушені впроваджувати і фінансову культуру високого рівня, в тому числі залучати до цього процесу клієнтів. Надання комплексних послуг повинно супроводжуватись і системною роботою по підвищенню фінансової грамотності клієнта, який повинен реально оцінювати свої ризики, а також планувати свої доходи та видатки.

Створення фінансової екосистеми базується на формуванні ефективних партнерських відносин 3 технологічними компаніями та старт-апами. Саме банки є одними із основних ініціаторів, що впроваджують сучасні фінансові технології, в багатьох випадках об'єднуючись із технологічними компаніями і інвестуючи кошти в високоефективні стартапи. За даними Міжнародного валютного фонду 13\% патентів в сфері фінансових послуг приходиться на ФінТех компанії, при цьому останні отримали $1 / 4$ суми фінансування венчурних та стартап-проєктів в розвитку фінансових послуг. Вони отримали 18 млрд дол, що становить 20\% від обсягу здійснених операцій первинного публічного розміщення акцій у фінансовому секторі на світовому фінансовому ринку.

Стосовно слабких сторін клієнтів - низький рівень фінансової грамотності клієнтів. Зниження рівня закритості персональної фінансової інформації, що може сприйматись клієнтами як загрози їх фінансовому стану. Також негативний вплив на формування фінансової екосистеми має відсутність якісного доступу до інтернету.

Слабкими сторонами в діяльності фінансових установ $є$ низький рівень фінансової інклюзії населення. Крім того для України є характерною ситуація щодо суттєвою нерівномірністю доступу до фінансових послуг між міським та сільським населенням. Крім того, за умови відсутності фізичного контакту може бути складно утримувати зв'язок з клієнтами, в перш чергу з фізичними особами, оскільки обслуговування юридичних осіб, особливо тих, які відносяться до категорії VIP-клієнтів в основному відбувається в традиційному режимі.

Однією з найбільш слабких сторін функціонування установ та подальшого розвитку фінансової екосистеми $є$ непристосованість законодавства та нездатність уряду і фінансових регуляторів швидко реагувати на появу нових фінансових інструментів. В зв'язку з цим важливим $є$ застосування нових підходів в регулюванні з використанням SupTech та RegTech.

Розвиток фінансової екосистеми створює нові можливості як для клієнтів, так і для самих установ. Впровадження концепції клієнтоцентризму передбачає створення профілю клієнта і дозволить задовольняти їх потреби шляхом формування персоналізованих пропозицій та винагороди. Водночас 
розвиток ФінТех та впровадження концепції клієнтоцентризму призводить до трансформації існуючих бізнес-моделей банків та інших фінансових установ та в подальшому може сприяти залученню широкого кола клієнтів. Зокрема в роботі [1] авторами визначено 4 рівні розвитку банків: «традиційний банкінг (роздрібний і приватний банкінг, корпоративний та інвестиційний банкінг); діджитал-банкінг (формування профілю клієнта та омніканальність); відкритий банкінг (початок формування екосистеми із залученням третіх осіб із кола нефінансових установ, налагодження співпраці на основі використання API технологій); відкритий X (банки здатні використовувати інформацію й створювати спільний ринок через ефективну співпрацю з фінансовими та нефінансовими установами задля всебічного задоволення потреб клієнтів)».

Водночас особливості формування фінансової екосистеми створюють загрози як для клієнтів, так і для фінансових установ, які є спільними для обох. Найбільшою загрозою є високий рівень кіберзлочинності. Зокрема за даними огляду компанії PwC [16] станом на 2020 рік кіберзлочини посіли другу позицію, поступившись місцем шахрайству з боку клієнтів. На третій позиції серед всіх економічних злочинів знаходиться незаконне заволодіння активами, а на четвертій - корупція.

При цьому, якщо аналізувати в розрізі видів економічної діяльності, зокрема при наданні фінансових послуг, то злочини розподілились наступним чином: шахрайство з боку клієнтів - 27\%, кіберзлочини 15\%; шахрайство з бухгалтерською та/або фінансовою звітністю - 14\%. За даними компанії Форіншурер протягом 2018 - 2020 років збитки від кіберзлочинів та витрати на захист від них збільшились майже в два рази - 3600 млрд дол у 2018 до 1.1 трлн дол у 2020 році. При цьому крадіжка інтелектуальної власності та злочини у фінансовій сфері становлять 75\% отриманих збитків [5].

На основі проведеного SWOT аналізу було сформовано чотири базові стратегії реструктуризації фінансової системи, які покладено в основу пропозицій щодо формування фінансової екосистеми та зміни бізнес-моделей функціонування її суб’єктів (Рисунок 3).

Системне вирішення проблемних питань дозволить створити умови щодо нівелювання можливих загроз та перетворити наявні слабкі сторони функціонування на сучасному етапі, на сильні та створити реальні перспективи для ефективної реструктуризації фінансової системи України.

\begin{tabular}{|c|c|c|c|}
\hline \multicolumn{2}{|c|}{$\begin{array}{c}\text { Інтенсивний інноваційний розвиток. Посилення } \\
\text { фінансової стійкості. } \\
\text { Зниження ризиків прояву кризи. }\end{array}$} & \multicolumn{2}{|c|}{$\begin{array}{c}\text { Інтенсивний інноваційний розвиток за умови } \\
\text { запровадження заходів нівелювання впливу } \\
\text { зазначених загроз. } \\
\text { Висока ймовірність формування кризових явищ. }\end{array}$} \\
\hline$S$ & W & $\mathrm{S}$ & W \\
\hline $\mathrm{O}$ & $\mathrm{T}$ & $\mathrm{O}$ & $\mathrm{T}$ \\
\hline \multicolumn{2}{|c|}{$\begin{array}{c}\text { Повільний розвиток фінансової системи, який } \\
\text { стає результатом запиту з боку обмеженого } \\
\text { кола споживачів фінансових послуг на фоні } \\
\text { низького рівня фінансової грамотності та } \\
\text { фінансової інклюзі1, в умовах непристосованого } \\
\text { законодавчого поля. Високий рівень прояву } \\
\text { кризи, обумовлений зростанням кількості } \\
\text { неякісних фінансових активів. }\end{array}$} & \multicolumn{2}{|c|}{$\begin{array}{c}\text { Уповільнення економічного розвитку на фоні } \\
\text { стискання фінансової системи. Поєднання } \\
\text { слабких сторін на фоні зростання загроз є } \\
\text { основою для перманентного стану фінансової } \\
\text { нестабільності. }\end{array}$} \\
\hline $\mathbf{S}$ & $\mathbf{W}$ & $S$ & W \\
\hline O & $\mathbf{T}$ & O & $\mathbf{T}$ \\
\hline
\end{tabular}

Рисунок 3. Стратегії розвитку фінансової системи України за результатами проведеного SWOT аналізу 


\section{ВИСНОВКИ}

Результати проведеного дослідження дозволили сформувати рекомендації щодо реалізації варіантів стратегій розвитку фінансової системи України з врахуванням досвіду провідних країн світу. Перша стратегія передбачає поєднання на основі сформованих сильних сторін та потенційних можливостей, по суті передбачає інноваційний розвиток фінансової системи та перетворення їі на таку фінансову екосистему, що базується на використанні вже існуючих та постійному впровадженні новітніх фінансових технологій, які роблять зручними та доступними фінансові послуги для широкого кола клієнтів як фізичних так і юридичних осіб. Формування фінансової екосистеми з врахуванням визначених сильних сторін та можливостей передбачає і зростання довіри до фінансових інститутів, що сприятиме нарощенню фінансової глибини економіки та посиленню її фінансової стійкості, а отже дозволить забезпечити зниження ризику прояву кризових явищ в національній економіці.

Друга стратегія характеризується підходами на основі забезпечення інтенсивного інноваційного розвитку, з орієнтацією на сильні сторони. Але за умови виникнення визначених в роботі загроз це може привести до зниження рівня фінансової стійкості в цілому. Особливо це стосується можливоі перспективи монополізації фінансового ринку та приведення його до стану, коли спостерігається значна залежність від стану публічних фінансів України, що проявляється через зростання розміру активів державних банків на фоні стискання розмірів фінансової системи.

Обгрунтовано, що не менш важливим буде необхідність вирішення питання щодо формування стандартів надання діджиталізованих послуг та захисту інформації. В цьому контексті важливим залишається у подальому активність не лише фінансових регуляторів, а й саморегулівних організацій фінансового ринку. Їх активність може в значній мірі сприяти корекції існуючих слабких сторін на етапі формування фінансової системи в Україні.

Третя стратегія базується на використанні потенційних можливостей, що отримують клієнти і фінансові установи в умовах розвитку фінансової системи з низьким рівнем фінансової інклюзії та фінансової грамотності за наявності невідповідної законодавчої бази, яка не дозволяє реалізувати існуючі переваги.

В залежності від темпів і параметрів розвитку економіки характер зміни стратегій діяльності окремих фінансових установ, зміни їх бізнес-моделей та інтенсивності просування ними нових видів фінансових послуг може суттєво покращитись рівень фінансової грамотності населення та зрости рівень фінансової інклюзії. Саме під тиском таких змін фінансові регулятори будуть змушені вживати заходи 3 врегулювання процедур надання фінансових послуг, зміни вимог щодо відповідності фінансового стану установ, а також посилення законодавчих вимог в частині забезпечення достатнього рівня їх кібербезпеки. Водночас, якщо визначені слабкі сторони не будуть нівелюватись, то загрози зниження фінансової стабільності можуть суттєво зростати, оскільки клієнти, не будуть мати можливості реально прогнозувати параметри своїх грошових потоків, та не в змозі будуть об’єктивно оцінювати свої ризики. Такий стан речей може привести до зростання розміру фінансових активів низької якості, формування значного пулу непрацюючих кредитів, тощо. Наслідком цього може стати активізація проявів фінансової кризи.

Четверта стратегія $€$ найгіршим варіантом можливого розвитку фінансової системи, який характеризується перспективою уповільнення всіх процесів, подальшого стискання розміру фінансової системи країни, зростання домінуючої ролі держави, що буде призводити у подальому до зниження рівня конкурентоздатності фінансових установ. Наслідком реалізації такого варіанту стратегії розвитку $€$ неминуче зниження фінансової стійкості та значна ймовірність виникнення кризових явищ в національній економіці. 
Отже, з метою здійснення ефективної рестуктуризації національної фінансової системи, перетворення iї на сучасну фінансову екосистему необхідно дотримуватись підходів з реалізації комплексу заходів визначених варіантів першої або ж другої стратегії, які передбачають активну позицію всіх учасників фінансових відносин. 3 одного боку фінансових установ, які мають максимально швидко запроваджувати якісні види фінансових послуг на основі сучасних фінансових технологій, з іншого боку - клієнтів, які мають підвищити рівень фінансової обізнаності, навчитись планувати свої доходи та видатки, оцінювати свої фінансові ризики, надаючі перевагу тим чи іншим видам фінансових послуг.

Важливим моментом визначеної проблематики залищається наявність проактивної поведінки фінансових регуляторів в частині реалізації спільних зусиль влади щодо створення нормативної бази, адекватної змінам і стратегічним орієнтирам розвитку фінансової системи, що вбачається напрямом подальших наукових досліджень.

\section{AUTHORS CONTRIBUTIONS}

Conceptualization: Sergiy Frolov.

Data curation: Volodymyr Orlov.

Formal Analysis: Sergiy Frolov, Olha Lozynska, Fathi Shukairi.

Funding acquisition: Volodymyr Orlov.

Investigation: Volodymyr Orlov, Olha Lozynska, Fathi Shukairi.

Methodology: Sergiy Frolov.

Project administration: Fathi Shukairi.

Resources: Volodymyr Orlov, Olha Lozynska.

Software: Fathi Shukairi.

Supervision: Sergiy Frolov.

Validation: Volodymyr Orlov.

Visualization: Olha Lozynska.

Writing - original draft: Sergiy Frolov, Fathi Shukairi.

Writing - review \& editing: Olha Lozynska.

\section{СПИСОК ЛІТЕРАТУРИ}

1. Blahun, I. (2020). Bankivska systema Ukrainy v umovakh turbulentnosti finansovoho rynku: teoriia, metodolohiia, praktyka [The banking system of Ukraine in conditions of financial market turbulence: theory, methodology, practice] (364 p.). Ivano-Frankivsk: Vasyl Stefanyk Precarpathian National University Vasyl Stefanyk Precarpathian National University. (In Ukrainian)

2. Cerra, V., \& Saxena, S. (2018). The economic scars of crises and recessions. IMFBlog. Retrieved from https://blogs.imf.org/2018/03/21/theeconomic-scars-of-crises-and-recessions

3. Čihák, M., \& Sahay, R. (2020). Finance and Inequality (51 p.). IMF Staff Discussion Note. Retrieved from https://doi. org/10.5089/9781513526546.006

4. Dovhan, Zh. (2019). Development of banking ecosystems: risks and prospects. Innovative economy, 5-6(80), 158-164. (In Ukrainian). https://doi.org/10.37332/2309-1533.2019.5-6.22

5. Forinsurer (2020). Ubytki ot kiberprestupnosti v mire vyrosli za dva goda na 50\% do \$ $945 \mathrm{mlrd}$ [Losses from cybercrime in the world have grown by $50 \%$ in two years to $\$ 945 \mathrm{bln}$ ] (In Rusian). Retrieved from https://forinsurer.com/news/20/12/10/38866

6. Georgieva, K. (2020). The Financial Sector in the 2020s: Building a More Inclusive System in the New Decade. International Monetary Fund. Retrieved from https://www.imf.org/en/News/Articles/2020/01/17/sp01172019-the-financial-sector-in-the-2020s

7. Kolodiziev, O., \& Lozynska, O. (2020). Features of Definition and Structurization of the_Market of Financial Services in the Conditions of Digitalization of Economy. Bankivska sprava - Banking, 2(152), 41-57. (In Ukrainian). Retrieved from http://repository.hneu.edu.ua/ handle/123456789/25099

8. Kolodiziev, O., Krupka, M., Shulga, N., Kulchytskyy, M., \& Lozynska, O. (2021). The level of digital transformation affecting the competitiveness of banks. Banks and Bank Systems, 16(1), 81-91. http://dx.doi.org/10.21511/bbs.16(1).2021.08

9. Kolodiziev, O., Lebid, O., \& Hryhorenko, V. (2017). Finansove zabezpechennia vprovadzhennia tekhnolohii ta innovatsii [Financial providing introduction of technologies and innovations] (261 p.). Kharkiv: Simon Kuznets Kharkiv National University of Economics. (In Ukrainian). Retrieved from http://www.repository.hneu.edu.ua/handle/123456789/19956

10. Li, S., Liu, X., \& Wang, C. (2020). The influence of internet finance on the sustainable development of the financial ecosystem in China. Sustainability, 12(6). http://dx.doi.org/10.3390/su12062365 
11. Lozynska, O. (2021). Analiz tendentsii i perspektyv tsyfrovizatsii finansovoho rynku Ukrainy [Analysis of trends and prospects for digitalization of the financial market of Ukraine]. In Materialy Mizhnarodnoi naukovo-praktychnoi konferentsii "Priorytety finansovo-ekonomichnoho upravlinnia" [Proceedings of the International Scientific and Practical Conference "Priorities of Financial and Economic Management"] (pp. 63-67). Odesa: Skhidnoievropeiskyi tsentr naukovykh doslidzhen. (In Ukrainian)

12. Metrick, A., \& Rhee, J. (2018). Regulatory reform. Annual Review of Financial Economics, 10, 153-172. http://dx.doi.org/10.1146/annurev-financial-110217-022646

13. National Bank of Ukraine (2020). Putivnyk dlia nebankivskykh finansovykh ustanov [Guide for non-bank financial institutions] (36 p.). (In Ukrainian). Retrieved from https://bank.gov.ua/admin_uploads/article/Guide-book_for_non-bank_financial_institutions.pdf?v=4

14. National Bank of Ukraine (n.d.). Finansova inkliuziia [Financial inclusion]. (In Ukrainian). Retrieved from https://old.bank.gov.ua/control/uk/publish/article?art_id=3961976

15. National Bank of Ukraine (n.d.). Strategy of Ukrainian Financial Sector Development until 2025. Retrieved from https://bank.gov.ua/en/ about/develop-strategy

16. PwC (2020). Fighting fraud: A never-ending battle. PwC's Global Economic Crime and fraud Survey (14 p.). Retrieved from https://www. pwc.com/gx/en/forensics/gecs-2020/pdf/global-economic-crime-and-fraud-survey-2020.pdf

17. USAID (2019). Finansova hramotnist, finansova inkliuziia ta finansovyi dobrobut $v$ Ukraini [Financial literacy, financial inclusion and financial well-being in Ukraine] (49 p.). (In Ukrainian). Retrieved from http://www.fst-ua.info/wp-content/uploads/2019/06/FinancialLiteracy-Survey-Report_June2019_ua.pdf?fbclid=IwAR2AlpnGNn8big9d0_v6YEhNBwL69ErT0ToDVmY5Rq8dIJqSvLVndCm5ueM

18. Verkhovna Rada of Ukraine (2021). Pro zatverdzhennia Polozhennia pro vymohy do struktury vlasnosti nadavachiv finansovykh posluh [On approval of the Regulation on requirements for the ownership structure of financial service providers]. (In Ukrainian). Retrieved from https:// zakon.rada.gov.ua/laws/show/v0030500-21\#Text 